\title{
A Novel Insulinotropic Peptide from the Skin Secretions of Amolops loloensis Frog
}

\author{
Guo-Xiang Mo $\cdot$ Xue-Wei Bai $\cdot$ Zong-Jie Li $\cdot$ \\ Xiu-Wen Yan $\cdot$ Xiao-Qing He $\cdot$ Ming-Qiang Rong
}

Received: 30 June 2014/ Accepted: 21 August 2014/Published online: 8 October 2014

(C) The Author(s) 2014. This article is published with open access at Springerlink.com

\begin{abstract}
Various kinds of biologically active peptides have previously been isolated from the skin secretions of Amolops loloensis frog, such as antimicrobial peptides, bradykinin-like peptides and algesic peptides. A novel insulinotropic peptide named amolopin was identified in A. loloensis frog's skin secretion. Its primary structure sequence was determined by Edman degradation as: FLPIVGKSLSGLSGKL-NH2. BLAST search indicates that the amino acid sequence of amolopin is quite different from other known insulin secretagogues, including mastoparan, exendins and $\alpha$-latrotoxin, nor does it like incretins (e.g. glucagons like peptide-1 and glucose-dependent insulinotropic ploypeptide) either. However, amolopin shows certain structural similarity with amphibian antimicrobial temporins and vespid chemotactic peptides isolated from Vespa magnifica. Amolopin can stimulate insulin release in INS-1 cells in a dose-dependent manner. Primary investigation on its action mechanisms reveals that amolopin does not increase the influx of $\mathrm{Ca}^{2+}$. In conclusion, a novel 16-amino acid peptide with insulin-releasing activity is initially discovered from the skin secretion of A. loloensis frog. Further work is necessary to evaluate its potential as novel anti-diabetic candidate.
\end{abstract}

Keywords Insulinotropic peptide $\cdot$ Amolops loloensis $\cdot$ Skin secretion $\cdot$ Insulin-releasing $\cdot$ Frog

\section{Introduction}

Amphibian skin granular gland secretions are consistently recognized as rich sources of multiple biologically active compounds [1], such as antimicrobial peptides (AMPs) [2], bradykinins, biogenic amines, complex alkaloids, etc. These compounds are of great importance for the amphibians to regulate their physiological balance, to resist infection by microorganism, and to escape from being preyed upon by natural predators.

G.-X. Mo · X.-W. Bai · Z.-J. Li · X.-W. Yan

School of Biological Sciences, Nanjing Agriculture University,

Nanjing 210095, Jiangshu, China

X.-Q. He · M.-Q. Rong ( $₫)$

Kunming Institue of Zoology, Chinese Academy of Sciences,

Kunming 650223, Yunnan, China

e-mail: rongmingqiang@mail.kiz.ac.cn
Insulinotropic peptides are various kinds of protein molecules that can stimulate insulin secretion by the pancreatic islets $\beta$-cells through different pathways. Over the past decades, several families of insulinotropic peptides have been discovered in lizard venoms [3], snake venoms [4], wasp venoms [5], the black widow spider toxins [6] and so forth. Exentides (exentide-1, -2, -3 and -4) isolated from lizard venoms belong to the glucagon superfamily peptides, most of which are structurally homologous and can increase insulin release, including glucagon-like peptide 1, glucose-dependent insulinotropic polypeptide, pituitary adenylate cyclase-activating polypeptide, vasoactive intestinal peptide and other members. The glucagon superfamily peptides are usually single-chain peptides consisting of 27-39 amino acids. However, insulinreleasing peptides purified from snake venoms and spider venoms (e.g. PLA 2 and $\alpha$-LTX) are commonly much larger polymers with molecular weights around 12-130 kDa, which are assembled of several subunits [7, 8]. 
Mastoparans and temporins are the smallest insulinotropic peptides obtained respectively from wasp venoms and amphibian skin secretions. Native mastoparan is a tetradecapeptide stimulating insulin secretion at a late stage in the secretary pathway $[9,10]$. While temporins, the smallest antibacterial peptides from the skin of Rana temporaria, bear insulin-releasing activity with a length of merely 10-13 amino acids [11, 12].

As the work of isolating novel insulinotropic peptides and characterizing the insulin-releasing activity of known bioactive peptides are focused on, several new insulinotropic peptides have been isolated from skin secretions of amphibian [13-16]. Simultaneously, due to our previous study, the skin secretions of frog Amolops loloensis comprised multiple kinds of biologically active polypeptides, including bradykinin-like peptide [17], antibacterial peptides [18] and algesic peptides [19]. It is very interesting to identify new insulinotropic peptides in A. loloensis's skin secretion and assess their acting mechanism. In this paper, we elucidated the isolation and structural characterization of novel insulinotropic peptides in the skin secretion of rufous-spotted torrent frog, A. loloensis.

\section{Materials and Methods}

\subsection{Collection of Frog Skin Secretions}

Adult specimens of A. loloensis of both sexes $(n=30$; weight range $30-40 \mathrm{~g}$ ) were collected in Yunnan Province of China. Skin secretions were collected as the following: frogs were put into a cylinder container. A piece of absorbent cotton immersed with anhydrous ether was put on the top of the container. The container was covered with a lid and permeated with volatilized anhydrous ether. Being stimulated by anhydrous ether for 1-2 min, frog skin surface was seen to exude copious secretions. Skin secretions were collected by washing the dorsal region of each frog with $0.1 \mathrm{M} \mathrm{NaCl}$ solution (containing 0.01 M EDTA). The collected solutions (500 $\mathrm{mL}$ of total volume) were quickly centrifuged and the supernatants were lyophilized.

\subsection{Peptide Purification}

Lyophilized skin secretion sample of A. loloensis (1.5 g, total $\mathrm{OD}_{280 \mathrm{~nm}}$ of 400 ) was dissolved in $10 \mathrm{~mL} 0.1 \mathrm{M}$ phosphate buffer, $\mathrm{pH} 6.0$, containing $5 \mathrm{mM}$ EDTA. The sample was applied to a Sephadex G-50 (Superfine, Amersham Biosciences, $2.6 \times 100 \mathrm{~cm}$ ) gel filtration column equilibrated with $0.1 \mathrm{M}$ phosphate buffer, $\mathrm{pH}$ 6.0. Elution was performed with the same buffer, collecting fractions of $3.0 \mathrm{~mL}$. The absorbance of the elute was monitored at $280 \mathrm{~nm}$. The insulin-releasing activities of fractions were determined as indicated below. The protein peaks revealed insulin-releasing activity were pooled, lyophilized, and re-suspended in $2 \mathrm{~mL} 0.1 \mathrm{M}$ phosphate buffer solution, $\mathrm{pH}$ 6.0, and purified further by $\mathrm{C}_{18}$ reverse phase high performance liquid chromatography (RP-HPLC, Hypersil BDS $\mathrm{C}_{18}, 300.46 \mathrm{~cm}$ ) column.

\subsection{Structural Analysis}

Complete peptide sequencing was undertaken by Edman degradation on an Applied Biosystem pulsed liquid-phase sequencer, model 491. Fast atom bombardment (FAB) mass spectrometry was carried out on an Autospec-3000 spectrometer, equipped with a high field magnet, using glycerol: 3-nitrobenzylalcohol: dimethylsulphoxide (1:1:1,v:v:v) as mixed matrix. The ion gun was operated at $25 \mathrm{kV}$ with a current of $1 \mu \mathrm{A}$ using $\mathrm{Cs}^{+}$as the bombarding gas.

\subsection{Insulin Secretion Assay}

The rat insulinoma INS-1 cells were cultured in RPMI1640 medium containing $1 \mathrm{mM}$ D-glucose and supplemented with $10 \%$ fetal calf serum, $100 \mathrm{U} / \mathrm{mL}$ penicillin, $100 \mathrm{mg} / \mathrm{mL}$ streptomycin, $10 \mathrm{M}$ HEPES, $2 \mathrm{M}$ L-glutamine, $1 \mathrm{M}$ sodium pyruvate, and $50 \mu \mathrm{M} \beta$-mercaptoethanol [20]. Culture medium was replaced every 2-3 days. After cells grew to near confluence, they were treated with $0.25 \%$ trypsin and $0.02 \%$ EDTA for $5 \mathrm{~min}$ and replated on $25-\mathrm{cm}^{2}$ flasks.

The insulin secretion assay method was modified as previously reported $[13,21]$. INS- 1 cells were harvested with trypsin/EDTA, seeded into 24 -well plates at a density of $3-5 \times 10^{5}$ cells $/ \mathrm{mL}$, and allowed to attach overnight. Before insulin-releasing assay, cells were preincubated in $1 \mathrm{~mL}$ Krebs-Ringer bicarbonate (KRB) buffer without glucose $\left(115 \mathrm{mM} \mathrm{NaCl}, 4.7 \mathrm{mM} \mathrm{KCl}, 1.28 \mathrm{mM} \mathrm{CaCl}_{2}\right.$, $1.2 \mathrm{mM} \mathrm{KH}_{2} \mathrm{PO}_{4}, 1.2 \mathrm{mM} \mathrm{MgSO}$, $10 \mathrm{mM} \mathrm{NaHCO}_{3}$ and $1 \mathrm{~g} / \mathrm{L} \mathrm{BSA}, \mathrm{pH} 7.4$ ) at $37{ }^{\circ} \mathrm{C}$ for $45 \mathrm{~min}$. Cells were incubated in the absence or presence of peptide venoms for $1 \mathrm{~h}$, using the same buffer supplemented with $2.8 \mathrm{mM}$ glucose. This glucose concentration enabled to detect the basal condition of insulin secretion. The insulin supernatants were collected, stored at $-20{ }^{\circ} \mathrm{C}$, and subsequently determined by radioimmunoassay.

\subsection{Measurement of $\left[\mathrm{Ca}^{2+}\right]_{\mathrm{i}}$}

To confirm whether the stimulatory mechanism of insulin secretion was via the activation of voltage-dependant channel $\mathrm{Ca}^{2+}$ (VDCC, the cytosolic concentration of $\mathrm{Ca}^{2+}$ was measured with fluorescent $\mathrm{Ca}^{2+}$ probe Fluo-3/AM (Dojindo Laboratories, Japan) according to formerly described [22-24]. INS-1 cells were plated onto glass 
bottom dishes (MatTek Corporation) and cultured overnight, and then $5 \mu \mathrm{M} / \mathrm{DMSO}$ Fluo-3/AM plus Pluronic F127 was added. The cells were loaded for $30 \mathrm{~min}$, washed three times with HEPES buffer saline $(10 \mathrm{mM}$ HEPES, $1 \mathrm{mM} \mathrm{Na}_{2} \mathrm{HPO}_{4}, 137 \mathrm{mM} \mathrm{NaCl}, 5 \mathrm{mM} \mathrm{KCl}, 1 \mathrm{mM} \mathrm{CaCl}_{2}$, $0.5 \mathrm{mM} \mathrm{MgCl}_{2}, 5 \mathrm{mM}$ glucose, $0.1 \%$ BSA, pH 7.4), and scanned with a confocal laser fluorescent microscope $(40 \times$ objective lens). The fluorescence was excited at $480 \mathrm{~nm}$ at 10 -s intervals and detected at $515 \mathrm{~nm}$, whose intensity were imaged after incubated with peptide venoms to indicate the $\left[\mathrm{Ca}^{2+}\right]_{\mathrm{i}}$ of individual cells.

\subsection{Statistical Analysis of the Data}

The statistical analysis of the data was carried out by SPSS statistical software. The results were expressed as the mean \pm SEM of five experiments. While comparing the change, the data was analyzed by one-way ANOVA, followed by the LSD to detect significant difference between different groups. The level of significance was set at $P<0.05$.

\section{Results}

\subsection{Purification of Insulinotropic Peptide}

The supernatant of $A$. loloensis skin secretions was divided into five peaks by Sephadex G-50 as report in our previous work [25]. A insulin-releasing activity peptide was firstly found and then an RP-HPLC column was used in order to get the purified insulin-releasing activity was peptide.

\subsection{Structural Analysis}

The purified insulinotropic peptide designated as amolopin was subjected to amino acid sequence analysis by automated Edman degradation. The amino acid sequence of amolopin was determined as: FLPIVGKSLSGLSGKLNH2. This 16-amino acid peptide includes a C-terminally amidated residue. Its molecular weight analyzed by FAB mass spectrometry was $1615.5 \mathrm{Da}$, which was nearly identical to the theoretical molecular weight, $1615.98 \mathrm{Da}$. BLAST search showed that amolopin was quite different from other known insulinotropic peptides, e.g. mastoparans, the glucagon superfamily peptides, $\mathrm{PLA}_{2}$ from snake venoms, and $\alpha$-LTX from black widow spider venoms (Fig. 1). This revealed a new insulinotropic peptide. Analysis by the ExPASy MW/pI tool (http://www.expasy.org/ tools/pi_tool.html) indicated its predicted $\mathrm{pI}$ was 10 . As shown in Fig. 1, amolopin shows certain homology with brevinins and temporins AMPs from amphibian skin as well as vespid chemotactic peptides from vespid venoms [26].

\subsection{Insulin Secretion}

As shown in Fig. 2, amolopin exhibited markedly insulinreleasing activity on rat insulinoma INS-1 cells. After incubation for $1 \mathrm{~h}$ in $1 \mathrm{~mL}$ KRB buffer $(115 \mathrm{mM} \mathrm{NaCl}$, $4.7 \mathrm{mM} \mathrm{KCl}, 1.28 \mathrm{mM} \mathrm{CaCl}_{2}, 1.2 \mathrm{mM} \mathrm{KH}_{2} \mathrm{PO}_{4}, 1.2 \mathrm{mM}$ $\mathrm{MgSO}_{4}, 10 \mathrm{mM} \mathrm{NaHCO}$ and $1 \mathrm{~g} / \mathrm{L} \mathrm{BSA}, \mathrm{pH}$ 7.4) at $37{ }^{\circ} \mathrm{C}$. Amolopin augmented insulin secretion by INS-1 cells at different concentrations compared with $2.8 \mathrm{mM}$ glucose alone. The INS-1 cell line was widely used for insulin secretion researches, which was established from radiation induced tumor growing in medium with 2-ME ( $\beta$-mercaptoethanol) [20]. The INS-1 cells were used between 18 and 25 passages. The stimulatory effects of amolopin enhanced as the peptide concentrations added, and statistical analysis by SPSS 13.0 revealed that amolopin significantly increased insulin release at the concentrations of 12.5, 25 and $50 \mu \mathrm{g} / \mathrm{mL}$ (Fig. 2).

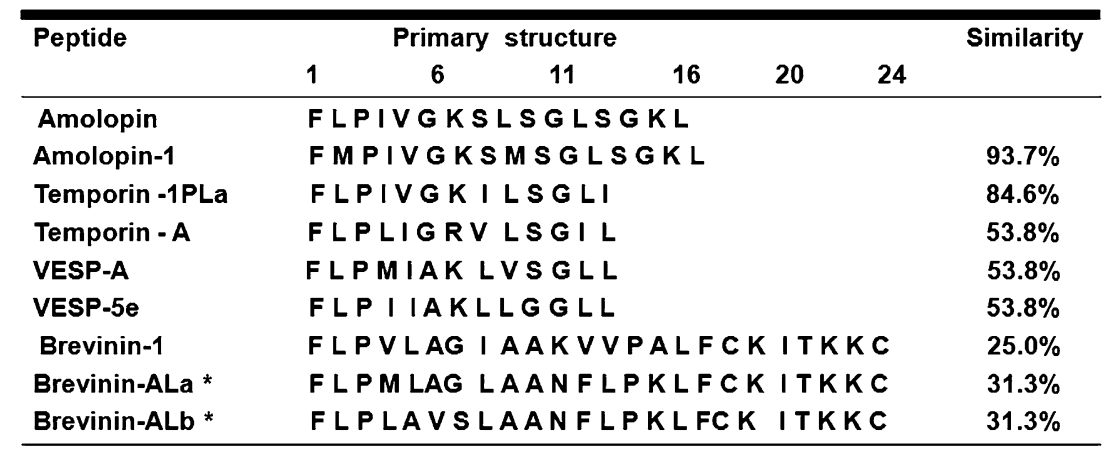

Fig. 1 The amino acid sequence comparison of amolopin with other bioactive peptides. Peptide amolopin is from this study, amolopin-1 from Amolops loloensis [25], temporin-1PLa from Rana palustris
[31], temporin-A from Rana temporaria [30], VESP-A and VESP-5e from Vespa magnifica [26], brevinin-1 from Rana brevipoda porsa [29] and brevinin-ALa, -ALb also from Amolops loloensis [18] 


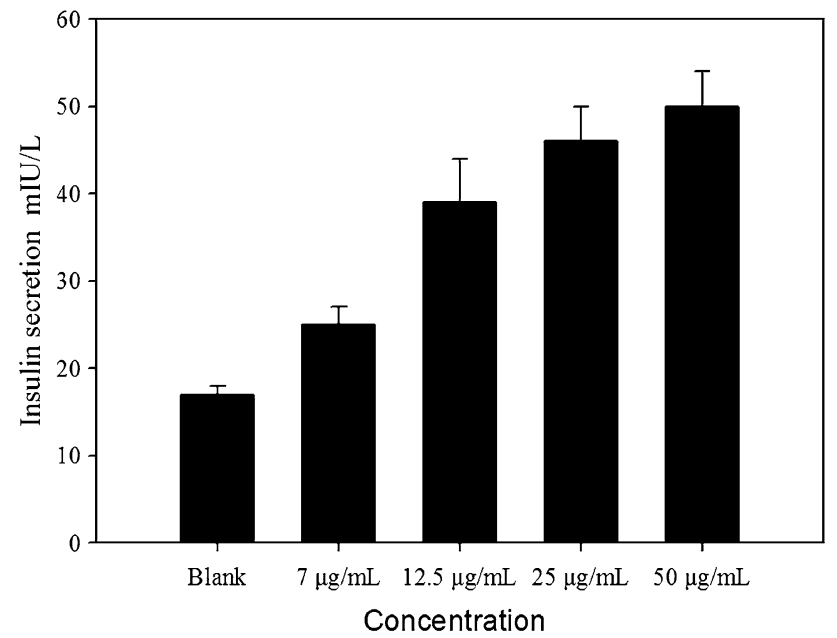

Fig. 2 The iusulinotropic effect of amolopin. Amolopin revealed obvious insulin-releasing activity on rat insulinoma INS-1 cells. The stimulation was quantified after $1 \mathrm{~h}$ incubation with peptide sample, compared with KRB buffer alone. The values are the means of \pm SEM for five independent experiments

\section{$3.4\left[\mathrm{Ca}^{2+}\right]_{\mathrm{i}}$ Imaging}

The cytosolic $\mathrm{Ca}^{2+}$ concentration was measured with fluorescent $\mathrm{Ca}^{2+}$ probe Fluo-3/AM to assess whether the insulin-releasing activity was induced by the activation of $\mathrm{Ca}^{2+}$ channel and $\mathrm{Ca}^{2+}$ influx. After the INS-1 cells were loaded with $10 \mathrm{mM}$ glucose and $5 \mu \mathrm{M}$ Fluo-3/AM, amolopin samples were added into incubation medium in the glass bottom dishes. The fluorescence indicating $\left[\mathrm{Ca}^{2+}\right]_{\mathrm{i}}$ was scanned by a confocal laser fluorescent microscope at 10 -s intervals. However, no significant increase in the fluorescence intensity was observed after the amolopin peptide was added. Though $\mathrm{Ca}^{2+}$ played a important role in the pathway of insulin exocytosis, this data confirmed amolopin stimulated insulin secretion not via $\mathrm{Ca}^{2+}$ influx. Experiments were repeated at least five times with similar results (Fig. 3).

\section{Discussion}

In the present study, a unique16-amino acid insulinotropic peptide termed amolopin was obtained from the skin secretion of A. loloensis by gel filtration and RP-HPLC, which was structurally different from other known insulinotropic peptides. A. loloensis frog belonged to Ranidae, Amolopinae [27, 28] and inhabited in Southeast Asiain torrent rivulets. Yet, numerous bioactive peptide had already been isolated from the skin secretion of A. loloensis, such as AMPs, bradykinin-like peptides and algesic peptides. These components might play a crucial role either in fighting against pathogenic germs, or in repelling

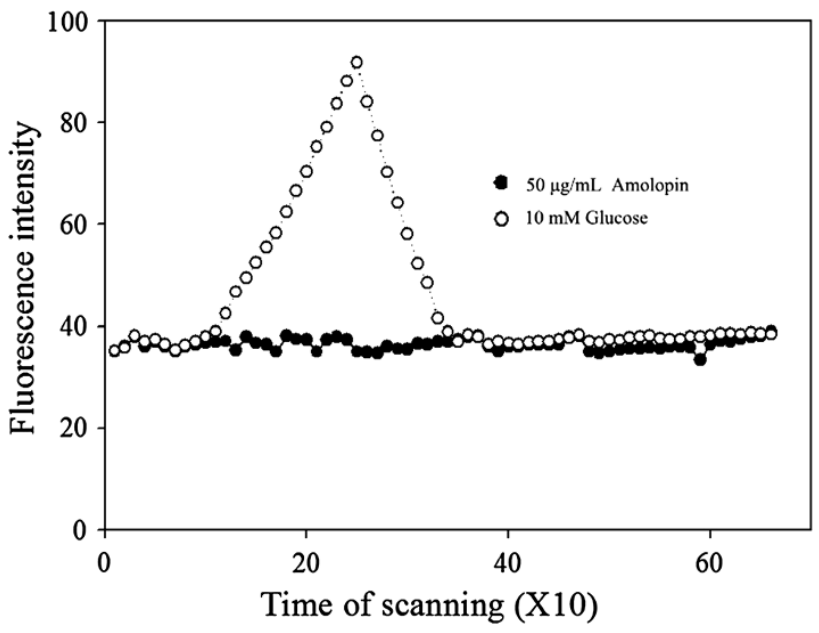

Fig. 3 Measurement of $\left[\mathrm{Ca}^{2+}\right]_{\mathrm{i}}$ in INS-1 cells. The INS-1 cells were loaded with $5 \mu \mathrm{M}$ Fluo-3/AM and washed three times with HEPES buffer saline. The cells were incubated in KRB buffer and scanned by a confocal laser microscope for $60 \mathrm{~s}$ as blank control. As indicated by the arrow, $10 \mathrm{mM}$ glucose and amolopin sample was added and scanned sequentially for another $10 \mathrm{~min} .\left[\mathrm{Ca}^{2+}\right]_{\mathrm{i}}$ indicated by the fluorescence intensity was measured. No evident increasing change of $\left[\mathrm{Ca}^{2+}\right]_{\mathrm{i}}$ and was observed after the addition of amolopin. Data is the means of five independent experiments

dangerous enemies by causing nociceptive responses. However, insulinotropic peptides might also possess approximate defence action through disturbing the physiological functions of their predator's endocrine organs and inducing hypoglycemia.

FAB mass spectrometry was employed to determine the molecular weight of amolopin and got the result of 1615.5 Da, which was almost identical to the theoretically calculated molecular mass 1615.98 Da by the ExPASy MW/pI tool (http://www.expasy.org/tools/pi_tool.html). Its sequence was assessed through the automated Edman degradation method as: FLPIVGKSLSGLSGKL-NH2. It belongs to the small molecular weight group of insulinotropic peptides together with mastoparans, temporins, and brevinins, distinctive from the large molecular weight group (e.g. PLA $\mathrm{P}_{2}$ from snake venoms and $\alpha$-LTX from black widow spider venoms) and the glucagon superfamily peptides. Brevinins are a family of antimicrobial peptides with the length of 24-amino acids initially isolated from the skin of Rana brevipoda porsa [29], and are found to have insulin-releasing activity [14, 16]. Temporins are also a large family of antimicrobial peptides with 13-residues firstly identified in the European red frog Rana temporaria [11], and other members were subsequently discovered in several North America Rana species, including R. clamitans, $R$. luteiventris, $R$. pipiens, $R$. grylio, and A. loloensis and $R$. palustris [18, 30, 31]. As multifunctional molecules, several temporins are proved to display insulin-releasing property [12]. 
According to Fig. 1, amolopin shares merely a little similarity with partial sequence of brevinins (brevinin-1, $25 \%$; -ALa, $31.3 \%$; -ALb, $31.3 \%$ ). However, it has certain homology with antimicrobial temporins (temporinA, $53.8 \%$; -1PLa, $84.6 \%$ ). What's more interestingly, amolopin is also similar to vespid chemotactic peptides (VESP-A; -5e both $53.8 \%$ ), which were detected from vespid venoms [25].

Insulin secretion assay, as illustrated Fig. 2, demonstrated that different concentrations of amolopin could significantly enhance insulin release by INS-1 clonal $\beta$-cells $(P<0.05)$, a cell line which was widely used for insulin secretion studies [32]. In order to investigate the stimulatory mechanism of amolopin, $\left[\mathrm{Ca}^{2+}\right]_{\mathrm{i}}$ was measured with Fluo-3 and confocal microscope. However, no evident $\mathrm{Ca}^{2+}$ influx increase was observed after the addition of amolopin. Therefore, amolopin stimulates insulin secretion probably not via activation of $\mathrm{Ca}^{2+}$ channel.

In summary, amolopin is a novel insulinotropic peptide characterized from the skin secretion of A. loloensis with distinctive primary structure. It may become a novel and promising anti-diabetic candidate after additional study to verify its efficacy and safety.

Acknowledgments This work was supported by National Natural Science Foundation (31200590), Jiangsu Province (BK2012365, BE2012748) and Yunan Province (2013FB072).

Conflict of interest The authors declare no conflict of interest.

Open Access This article is distributed under the terms of the Creative Commons Attribution License which permits any use, distribution, and reproduction in any medium, provided the original author(s) and the source are credited.

\section{References}

1. M. Simmaco, G. Mignogna, D. Barra, Biopolymers 47, 435-450 (1998)

2. J. Li, X. Xu, C. Xu, W. Zhou, K. Zhang, H. Yu, Y. Zhang, Y. Zheng, H.H. Rees, R. Lai, D. Yang, J. Wu, Mol. Cell. Proteomics 6, 882-894 (2007)

3. J.P. Raufman, Regul. Pept. 61, 1-18 (1996)

4. T.A. Nogueira, F. Ferreira, H.M. Toyama, F.L. Stoppiglia, S. Marangoni, A. Boschero, M.E. Carneiro, Toxicon 45, 243-248 (2005)
5. N. Yokokawa, M. Komatsu, T. Takeda, T. Aizawa, T. Yamada, Biochem. Biophys. Res. Commun. 158, 712-716 (1989)

6. A. Rohou, J. Nield, Y.A. Ushkaryov, Toxicon 49, 531-549 (2007)

7. C.A. Ashton, M.A. Rahman, E.K. Volynski, C. Manser, V.E. Orlova, H. Matsushita, A.B. Davletov, V.M. Heel, V.E. Grishin, A.Y. Ushkaryov, Biochimie 82, 453-468 (2000)

8. D.I. Israel, Nucleic Acids Res. 21, 2627-2631 (1993)

9. P.M. Jones, F.M. Mann, S.J. Persaud, C.P. Wheeler-Jones, Mol. Cell. Endocrinol. 94, 97-103 (1993)

10. H.R. Amin, H. Chen, R. Veluthakal, B.R. Silver, J. Li, A. Kowluru, Endocrinology 144, 4508-4518 (2003)

11. M. Simmaco, G. Mignogna, S. Canofeni, R. Miele, M.L. Mangoni, D. Barra, Eur. J. Biochem. 242, 788-792 (1996)

12. Y.H. Abdel-Wahab, L. Marenah, D.F. Orr, C. Shaw, P.R. Flatt, Biol. Chem. 386, 58-581 (2005)

13. L. Marenah, P.R. Flatt, D.F. Orr, S. McClean, C. Shaw, Y.H. Abdel-Wahab, J. Endocrinol. 181, 347-354 (2004)

14. L. Marenah, P.R. Flatt, D.F. Orr, C. Shaw, Y.H. Abdel-Wahab, Peptides 26, 2117-2123 (2005)

15. L. Marenah, P.R. Flatt, D.F. Orr, C. Shaw, Y.H. Abdel-Wahab, J. Endocrinol. 188, 1-9 (2006)

16. Y.H. Abdel-Wahab, L. Marenah, P.R. Flatt, J.M. Conlon, Protein Pept. Lett. 14, 702-707 (2007)

17. J. Liang, Y. Han, J. Li, X. Xu, H.H. Rees, R. Lai, Peptides 27, 2683-2687 (2006)

18. Y. Lu, J. Li, H. Yu, X. Xu, J. Liang, Y. Tian, D. Ma, G. Lin, G. Huang, R. Lai, Peptides 27, 3085-3091 (2006)

19. H. Yu, X. Wang, J. Liu, R. Lai, J. Pept. Sci. 13, 798-802 (2007)

20. M. Asfari, D. Janjic, P. Meda, G. Li, A.P. Halban, B.C. Wollheim, Endocrinology 130, 167-178 (1992)

21. E. Santini, P. Fallahi, M.S. Ferrari, A. Masoni, A. Antonelli, E. Ferranini, Diabetes 53, 79-83 (2004)

22. K.J. Mitchell, T. Tsuboi, G.A. Rutter, Diabetes 53, 393-400 (2004)

23. J. Fauconnier, D.C. Andersson, S.J. Zhang, J.T. Lanner, R. Wibom, A. Katz, J.D. Bruton, H. Westerblad, Diabetes 56, 1136-1142 (2007)

24. X. Hu, M. Jiang, J. Zhang, A. Zhang, F. Lin, M. Tan, New Phytol. 173, 27-38 (2007)

25. H. Feng, Y. Lv, M. Wang, J, Li. Zool. Res. 30, 165-170 (2009)

26. X. Xu, J. Li, Q. Lu, H. Yang, Y. Zhang, R. Lai, Toxicon 47, 249-253 (2006)

27. A. Dubois, Bull. Mens. Soc. Linn. Lyon. 61, 305-352 (1992)

28. C. Liu, Fieldiana Zool. Mem. 2, 1-400 (1950)

29. N. Morikawa, K. Hagiwara, T. Nakajima, Biochem. Biophys. Res. Commun. 189, 184-190 (1992)

30. M.L. Mangoni, J.M. Saugar, M. Dellisanti, D. Barra, M. Simmaco, L. Rivas, J. Biol. Chem. 280, 984-990 (2005)

31. M. Zhou, L. Wang, D.E. Owens, T. Chen, B. Walker, C. Shaw, Peptides 28, 1605-1610 (2007)

32. E.H. Hohmeier, B.C. Newgard, Mol. Cell. Endocrinol. 228, 121-128 (2004) 